\title{
THE CONCEPT AND ASSESSMENT OF THE IMPLEMENTATION OF AN INTEGRATED RAIL TICKET ON THE PASSENGER TRANSPORT MARKET
}

\author{
GRAŻYNA ROSA \\ University of Szczecin, Faculty of Management and Economics of Services, POLAND \\ e-mail: grazyna.rosa@wzieu.pl
}

RECEIVED
ACCEPTED
JEL
CLASSIFICATION

KEYWORDS

ABSTRACT
18 January 2018

2 September 2018

D12, L92

integrated rail ticket, passenger transport market

This article presents the concept of an integrated rail ticket with regard to the research on the railway services market, which shows that passengers, first and foremost, expect minimization of effort required to organize the transport, which can be achieved by an integrated railway ticket. The aim of this article is to present the concept and evaluation of the implementation of an integrated railway ticket on the passenger transport market. The research area constituted mass passenger transport (by railway undertakings) and individual transport by passenger cars in Poland. In order to achieve this goal, the desk research method was adopted, and supplemented by the available literature and the results of secondary research published by the Railway Transport Office and the Central Statistical Office (GUS). The latter opens new possibilities for railway undertakings in the scope of analysing passengers' expectations and shaping their communication behaviour.

\section{Introduction}

The modern transport market (both passenger and freight transport) is controlled by customers. The surplus of services offered on the passenger transport market is the result of the development of individual motorization, which satisfies a large part of the demand for transport on the market. 
According to Eurostat data, the number of cars per 1,000 inhabitants in Poland increased from 261 to 504 in 2000-2013. This is the largest increase in motoring ratio among the 28 European Union countries (The Railway Transport Office, 2017a, p. 7), which means that a potential rail transport customer in Poland has a real choice between a passenger car and a train.

The competition for service purchaser concerns, first and foremost, instruments such as product (time and convenience of travel, physical accessibility and number of connections) and price. Rolling stock is gradually renewed, both by motor and railway carriers (with the participation of the state and local governments), and customer service is improving. Drivers have at their disposal more and more expressways and highways, which in turn has improved the safety of travel by car and significantly shortened the travel time between major cities in Poland. Furthermore, the changes also concern passengers' communication patterns.

The aim of the article is to present the concept and evaluation of the implementation of an integrated railway ticket on the passenger transport market. The research area constituted mass passenger transport (by railway undertakings) and individual transport by passenger cars in Poland. In order to achieve this goal, the desk research method was adopted, and supplemented by the available literature and the results of secondary research published by the Railway Transport Office and the Central Statistical Office (GUS). The latter opens new possibilities for railway undertakings in the scope of analysing passengers' expectations and shaping their communication behaviour.

\section{The passenger transport market}

The exchange of information between parties and market participants, as well as negotiations, decisionmaking, or the examination of supply and demand, i.e., the collective process without which the transaction will not take place, is called the market and is possible due to the existence of exchange relations. The essence of every market, including the transport service market, is primarily the subject of activities carried out within it, as well as entities operating on its demand and supply side.

The basic factors affecting demand in passenger transport are: population, location and degree of concentration of settlements, level of economic development of the region, the society's purchasing power, time spent on various forms of activity, maintenance costs of personal transport equipment in relation to the prices of public transport services, the rank of particular requirements that make up the quality of the service offer. The most commonly mentioned requirements in the literature on passenger transport are:

a) travel comfort, including:

- an area at the disposal of the passenger when awaiting the transport, lighting, the possibility of making small purchases, the possibility of using catering services (factors related to the waiting phase),

- guaranteed number of seat capacity, air-conditioning, smooth running, low noise level, ventilation, interior design, good service culture, ease of boarding and disembarking, space for luggage, the possibility to take a rest during travel (factors related to the driving phase) (Wyszomirski, 1994 p. 21);

b) safety:

- lighting, protection against assaults (associated with the access phase),

- in means of transport,

- during the travel (collisions and catastrophes),

- system giving access to information on routing, time tables, the possibilities of connection and changing trains (related to the changing phase), 
- completeness,

- time.

At the same time, there can be observed factors increasing the demand for passenger transport services (especially individual transport) due to social, cultural and professional integration (McLuhan's theory "world a common village"), the rise in the standard of living and travel propensity related to it, development of tourism, removal of restrictions concerning movement of people, development of housing estates on the outskirts of large agglomerations, development of the school system and the need to obtain education, increasing number of business trips (to companies' headquarters in order to maintain contacts with customers and co-operators, and to increase employees' skills by participation in workshops, training courses, and obtaining certificates).

The supply of passenger transport services is implemented by transport companies and travel organizers possessing their own fleet, as well as travel agencies and other organizations seeking to satisfy the demand reported by potential and real buyers.

The key entities on the rail passenger transport market are companies such as PKP Przewozy Regionalne (the majority of agglomeration, regional and interregional trains), PKP Intercity (selected interregional trains and all inter-agglomeration trains - qualified, including international trains) and PKP Szybka Kolej Miejska in Tricity (agglomeration and regional trains). Since 2005, PKP Intercity has been offering a new category of trains under the name Cheap Railway Lines (TLK) (today: Your Railway Lines), which is a network of day and night connections. PKP assumes that the main advantage of TLK is safety and low price for the journey. TLK's offer is addressed to the less affluent clients, such as students, senior citizens, and pensioners.

An important problem concerning the operation of various carriers is the lack of instruments to coordinate their operation regarding preparation of transport offers, infrastructure operation, settlements, and the lack of an integrated service distribution system - a problem which is especially acute for customers. Requiring the passengers to investigate the passenger transport structure, which is diversified in terms of entities, e.g., by obtaining information, purchasing tickets at different ticket offices, understanding fee relations, preserving rights when changing the transport operator, results in further decrease of the already low evaluation of user-friendliness of the passenger transport system, which is generally considered unfriendly to passengers.

The main segments on the rail passenger transport market include inter-agglomeration, inter-regional, regional and agglomeration transport.

The subsystem of inter-agglomeration transport is characterized by influence of competitors on rail transport, achieved primarily by low prices (bus transport) and travel time (air transport). However, when taking into consideration the implementation of key transport demands such as comfort, travel time and safety, there may be observed a stable position of rail transport, often with an upward trend.

In the interregional transport segment, the essential tools of competition are travel time and price. In case of rolling stock, bus operators with a modern fleet are more competitive, especially when compared to the railway, which still uses outdated carriages. Moreover, many railway lines are still awaiting modernization, a fact that decreases the quality of services in the scope of travel time. Due to the large number of modernization works carried out, travel times offered by carriers are far from the expectations of travellers. The basic tools of competition are therefore additional services, travel comfort, and others. 
The following characteristics can be observed in the regional transport services:

- in the scope of commuting to large agglomerations, rail transport successfully competes with individual and bus transport,

- in the scope of regional services, road transport has a competitive advantage due to a greater accessibility and the possibility to organize transport "from door to door". In this transport segment, the competitiveness of railway has significantly increased as a result of the purchase of modern rolling stock offering high travel comfort by the local governments.

Agglomeration transport in the scope of road transport is more and more often characterised by problems regarding congestion and lack of parking space. In this context, there can be observed a relative increase in the position of railway. The problem is low travel comfort due to the still large number of obsolete rolling stock, which is lower than in modern buses or trams.

\section{Development opportunities of rail passenger transport in Poland}

The goals for increasing the use of railways in passenger transport in Poland in the coming years, as well as one of the basic opportunities, are the aims indicated in the "Transport White Paper" presented by the European Commission for 2050. In this scope, the experiences and solutions already implemented in other countries might prove quite useful. The country with the highest load factor for railways is Switzerland, where one resident travels 70 times a year. Travel by train in this country is characterized by (The Railway Transport Office, 2017a, p. 11):

- high railway availability (a large number of trains daily that run cyclically, e.g. every hour)

- reliability,

- travel comfort (comfortable and well-sounded carriages available even in regional trains),

- high level of connections with other means of transport and a wide offer of an integrated ticket for all means of transport.

As a consequence, a Pole travels by rail on average $400 \mathrm{~km}$ per year, whereas a Swiss 2,200 thousand kilometres, which is 5 times more.

Another driving factors for using services provided by railway undertakings are relatively high costs related to the usage of a car in the city.

The potential of railways in Poland and in other European countries can be compared on the basis of the average number of passenger trains running daily on the statistical kilometre of the railway line. In Poland, there are on average 20 trains running one kilometre of a railway line, i.e., 7 times less than in the Netherlands. The European average in this ranking amounts to 45 trains per $1 \mathrm{~km}$ of a railway line (The Railway Transport Office, 2017a, p. 11)

This problem was intensively exposed by passengers ${ }^{1}$ taking part in the research carried out by PKP Intercity. The remarks and suggestions submitted had shown that passengers are interested in participating in the creation of a network of connections.

If compared to other European countries, the average number of travels by train per a statistical resident of Poland is not high. An average European citizen travels by train 19 times a year, whereas the Pole only 8 . This

\footnotetext{
${ }^{1}$ Public consultations concerning the new offer presented by PKP Intercity for the 2017/2018 season implemented on 10 December, 2017, were held for one week, i.e., from 8 until 15 March 2017. The interactive questioner at PKP Intercity's website was used almost 3,600 times (Pasażerowie..., 2017).
} 
shows the untapped potential of the railways, despite the changes that have taken place in recent years. They are primarily reflected in the gradual increase in the number of travellers (The Railway Transport Office, 2017a, p. 12).

The number of passengers in Poland in 2015 reached the level of 280.3 million, which represented an increase of $4.2 \%$ compared to 2014 (269.1 million). This was also the first increase after 2012 (Report ..., 2017). The year 2016 brought another increase of $4.3 \%$ and ended with the result of 292.5 million passengers. The last time a similar result could be observed was in 2008 (see Figure 1). The number of 292.5 million passengers indicates, as mentioned earlier, that the average Polish citizen only travelled by train several times in 2016 (The Railway Transport Office, 2017a, p. 12). (The number of transported passengers divided by the number of inhabitants of Poland results in 7.6). ${ }^{2}$

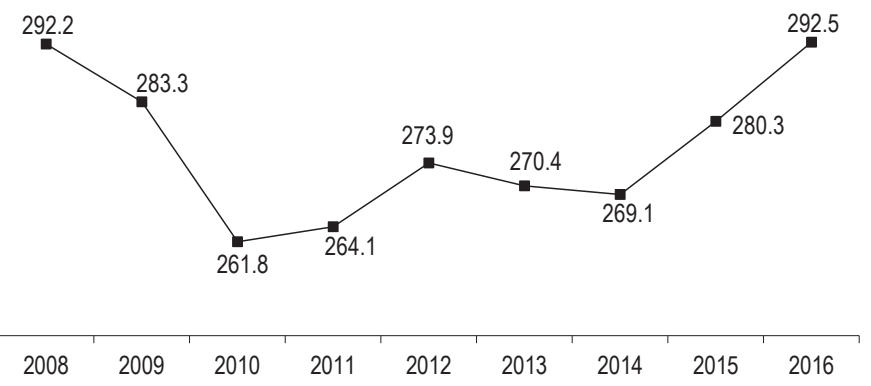

Figure 1. Number of passengers in rail transport in 2008-2016 (in millions)

Source: The Railway Transport Office (2017b), p. 3.

The research results indicate that the most important factors shaping consumer behaviour on the rail passenger transport market include:

a) product (offer) appropriately tailored to the needs of the region, which should:

- efficiently use modern rolling stock and better infrastructure,

- include, first and foremost, well-thought-out timetable (adjusted departure times, cyclicity of the timetable and frequency of running trains),

- offer an appropriate level of service;

b) include a wide offer of an integrated ticket for all means of transport:

- the infrastructure and location of stops in a manner enabling them to be used by the largest possible flow of travellers, as well as to adapt them to the needs of people with disabilities. It should be remembered that appropriately dense, but not adapted, infrastructure would not encourage passengers to use rail transport. In places where it is difficult to adjust the railway infrastructure, intermodality should be taken

2 In seeking to compare the condition of railways in particular voivodships, the RTO introduced the term "utilisation rate". It is calculated as a quotient of the number of passengers travelling by passenger trains (presented in the statistics as the number of passengers) and the number of inhabitants of a given area. In Poland, it reaches the level of 7.6 trips a year, which means that statistically in 2016, every Pole travelled almost eight times by train. The utilization rate is equal to the ratio of the number of passengers and the number of inhabitants of Poland. The number of passengers in 2016 was used for the calculation -292.5 million, as well as the number of inhabitants according to the Central Statistical Office data from January $2016-38.4$ million. The utilization rate calculated in this way amounted to 7.6. Wykorzystanie i potencjał... (2016), p. 2. 
into consideration (e.g. construction of parking lots in the form of "park and ride", city bikes, adjustment of the train timetable to city bus or tram timetables, creation of connecting points),

- reviewing and usage of solutions used in countries where railway realistically competes with passenger cars. The comparison of Poland with other EU countries shows that railway has the potential to increase its use in passenger transport.

The overall conclusion is that passengers expect comfortable and functional trains, adequate point infrastructure (stations, terminals, stops), its density, proper service level, timetable adapted to their needs and, above all, minimizing the effort involved in organizing the transport, which can be achieved thanks to an integrated railway ticket. Railway is a system where each of its elements matters and may have an effect on the final choice of means of transport by passengers (the Railway Transport Office, 2017b, p. 42).

\section{The concept and implementation of an integrated ticket for various railway undertakings}

There are several railway undertakings operating in Poland that offer various tariff schemes, discounts and special offers. An integrated ticket is an important factor that improves competitiveness of the entire public transport. This solution should go hand in hand with the creation of a coherent and complementary offer including the possibility of changing trains between different railway undertakings and different types of transport (Kuś, 2017).

A passenger who is planning a trip involving more than one carrier, when buying a ticket must very often consider how many they should have with them and whether they have not forgotten to buy some, changing to the train of another carrier.

The concept of an integrated ticket has been reflected in the strategic and programming documents, among others, in Transport Development Strategy until 2020. The strategy envisages integration of different transport modes, i.e.: "introduction of a ticket valid for all transport modes offered by every carrier on a regional and national scale (electronic ticket)."

The works on an integrated ticket carried out at the initiative of the Ministry of Infrastructure and Construction in 2016-2017 did not bring any agreement between railway undertakings controlled by the state and carriers belonging to voivodship self-governments. The issues concerning income settlement and ways of selling an integrated ticket were not agreed upon. Therefore, after a 2-month-period of declarations, discussions and works, two separate concepts of an integrated ticket were implemented in the second half of 2017 , which still do not allow passengers to purchase one ticket for rail travel, regardless of the chosen route or carrier.

Since September 2017, passengers can buy a ticket on one form for the travel of three carriers controlled by the state, i.e., PKP Intercity, Polregio and PKP SKM in Tricity. The so-called "Traveller package" allows passengers to purchase tickets for the whole journey at one ticket window, however, it is only available in designated ticket offices. This is a facility for customers that also allows them to save time, as they no longer have to wait in a couple of queues. Importantly, the introduced solution includes discounts and commercial offers of individual carriers, as well as the degressive nature of the tariff scheme. However, the ticket can be bought only at the ticket offices of the aforementioned carriers, which significantly limits its availability.

Since January 2, 2018, Łódzka Kolej Aglomeracyjna (Łódź Agglomeration Railway) joined the group of carriers offering their passengers tickets under the „Traveler Package”. Since January 15, 2018, the offer to buy a joint ticket is also available on internet. 
On the other hand, since August 2017, "Common Local Government Ticket" has been available. It is a personal ticket that costs PLN 38 and is not subject to statutory discounts. It entitles passengers to an unlimited number of journeys by scheduled trains of cooperating companies. It is valid for 24 hours from the date and time of purchase or the time specified by the buyer. The offer of the "Common Local Government Ticket" covers a total of 62 lines servicing over 950 stations in 12 voivodeships. It was prepared by eight mostly owned by the provincial self-governing companies: Koleje Mazowieckie (Masovian Railways), Warszawska Kolej Dojazdowa (the Warsaw Commuter Rail), Koleje Ślaskie (Silesian Rail Carrier), Koleje Małopolskie (Lesser Poland Railways), Arriva (from the Deutsche Bahn Group), Koleje Wielkopolskie (Wielkopolska Railways), Koleje Dolnośląskie (Lower Silesia Railways) and Łódzka Kolej Agglomeracyjna (Łódź Metropolitan Railway). By definition, the aim of "Common Local Government Ticket" is to encourage Polish citizens to travel by train and facilitate their transport between regions. In accordance with the offer, the ticket can be purchased 7 days in advance at ticket offices, ticket machines, via the Internet, or at other points of sale, as well as on the day of departure: on trains and via mobile applications. The evaluation of the "Common Local Government Ticket" project indicates that due to the limited scope of activities of individual self-government railway carriers, the offer does not include many trains which makes it difficult to plan longer journeys on one ticket, not to mention travel from one end of Poland to the other. The practical usefulness of this offer for passengers is therefore rather limited.

\section{Conclusions}

After many months of efforts by the Ministry of Infrastructure and Transport, state, local government and private transport operators, an integrated rail ticket still remains in the sphere of plans. The two implemented offers are not even competitive because they mostly refer to separate areas of transport activity. In their present form, they point to the efforts of the parties that have not come to an agreement.

The necessity to return to the concept of an integrated ticket accepted by all carriers is still present. Integration of tariff scheme in case of a carrier providing long-distance transport services, which cover cities in various regions, together with different local carriers, is still difficult to carry out. Therefore, the first step should be to integrate the tariff schemes of local government companies, and only then can such a combined system be integrated with the long-distance carrier's offer. Integration of tariff schemes is easier in case of interregional transportation that provide the same kind of service. The best solution would be a unified regional tariff scheme in Poland. Only then would it be possible to buy a ticket for the PKP Intercity train and then a regional tariff ticket under one system (Kuś, 2017).

\section{References}

Centrum Badań i Edukacji Statystycznej GUS (2015). Badanie pilotażowe zachowań komunikacyjnych ludności w Polsce, etap III raport końcowy, Jachranka.

Kuś, Ł. (2017). Finanse i przepisy przeszkodą przy tworzeniu wspólnego biletu. Retrieved from: https://kurierkolejowy.eu/ aktualnosci/30316/finanse-i-przepisy-przeszkoda-przy-tworzeniu-wspolnego-biletu.html.

Pasażerowie wyrazili opinie i preferencje dotyczące rozkładu jazdy PKP Intercity (2017). Retrieved from: https://www.intercity.pl/pl/ site/o-nas/dzial-prasowy/aktualnosci/pasazerowie-wyrazili-opinie-i-preferencje-dotyczace-rozkladu-jazdy-pkp-intercity.html.

Report on Rail Transport Market Operations in 2016 (2017). Urząd Transportu Kolejowego. Retrieved from: https://utk.gov.pl/pl/ aktualnosci/13293,Sprawozdanie-z-funkcjonowania-rynku-transportu-kolejowego-w-2016-r.html.

The Railway Transport Office (2017a). Wykorzystanie i potencjał kolejowych przewozów pasażerskich w Polsce. Warszawa. 
The Railway Transport Office (2017b). Koleje pasażerskie w województwach - dynamika zmian. Warszawa.

Wykorzystanie i potencjał kolejowych przewozów pasażerskich w Polsce (2016). Urząd Transportu Kolejowego. Retrieved from: https://utk.gov.pl/pl/raporty-i-analizy/analizy-i-monitoring/analizy-i-opracowania/12849,Wykorzystanie-i-potencjal-kolejowychprzewozow-pasazerskich-w-Polsce.html.

Cite this article aS: Rosa, G. (2018). The concept and assessment of the implementation of an integrated rail ticket on the passenger transport market. European Journal of Service Management, 3 (27/2), 363-370. DOI: 10.18276/ejsm.2018.27/2-44. 